\title{
Towards a framework of quality management for cooperative higher education
}

\author{
Jinhua $\mathrm{Li}^{1, \mathrm{a}}$, Yang Houjun ${ }^{2, \mathrm{~b}}$ \\ ${ }^{1}$ College of Information Engineering, Qingdao University, Qingdao, 266071, China \\ ${ }^{2}$ College of Information Engineering, Qingdao University, Qingdao, 266071, China \\ aemail: qduli@126.com, bemail: hjyang@qdu.edu.cn
}

\section{Keywords: Cooperative Education; Quality Management; TQM; PDCA}

\begin{abstract}
The qualities in cooperative education which embed work-integrated learning into the curricula propose challenges for higher education. To address the issues, a framework of quality management on the basis of total quality management and PDCA cycle is proposed. The framework consists of three components - quality assurance, quality control and quality improvement for co programs. All the activities in the components are structured according to the PDCA model. The paper describes the structure of the framework and the some specific activities of the quality management in cooperative education.
\end{abstract}

\section{Motivation}

With the rapid economic development and globalization, there has been a dramatic increasing need of students with higher education (HE) in the world [1]. In the past two decades, the number of graduated students from higher education institutions (HEIs) has been doubled. The traditional elite education has become massive education, which has made it more difficult for students to rely only on having a university degree to secure a good job after graduation. The industries are complaining that they cannot find appropriate workforce from the increasing number of university graduates. Employers expect specific professional skills from the new graduates, such as working experience, strong analytical reasoning, and being able to work effectively in a team. There is a giant gap between the HE and the industrial needs. Many HEIs are attempting to resolve the issues in different ways of cooperative education (co-op) that requires students to undertake relevant practical work experience by way of work placements, internships, or sandwich degrees [2].

The Education Department of China promotes a series of educational reforms and measures, including the program of excellent engineers' cultivation in HEIs and the different methods of co-op with industries, shifting the emphasis of HE from pure academic research to teaching practical expertise and technical skills. The educational reform is particularly of importance for the majority of HEIs in China, which make up more than 95\% of all Chinese HEIs. Conventional co-op programs are carried out mainly in vocational schools. Integration of work-integrated learning (WIL) into tertiary curricula is a relatively new attempt in China. The trend of massive education and various co-ops pose new challenges of quality management for Chinese HEIs [3].

The paper addresses the quality issues occurred in co-op of HE. The paper firstly gives an overview of the co-op development in HE, discusses quality management and various applications in HE. Based on the general principles of total quality management (TQM) and the PDCA cycle, a framework of quality management for higher co-op is presented. The framework composes three core components of quality assurance, quality control and quality evaluation. Their activities that are integrated into the PDCA cycle are conducted in the process of co-operative education.

\section{Cooperative Education and Quality Management}

Traditionally, there are three functions in HE: teaching, research and extensions such as service for community or government. The relationships between education and the economy have been publicly debated from different perspectives since the introduction of massive education. In the 
current knowledge society, HEIs are under increasing pressure to prepare graduates readiness of work to achieve the expectations of society. One of the chief roles of HE is to provide society with individuals who are trained so that they can respond to the demands of occupations, as well as demonstrating the skills necessary for participating in a global economy.

Co-op represents deliberate efforts to integrate traditional tertiary education with opportunities to develop knowledge and skills relevant to the contemporary workplace, thereby enhancing student capabilities beyond the limitations associated with traditional classroom instructions [2]. Different co-op programs are carried out in the world. They are characterized by diversity; in terms of the duration of WIL, the number of placements, and their 'location' within the degree structure [4-6]. Many benefits are described in the literature for all parties involved in co-op, including students, universities, and the community or country and industry partners [2, 7, 8]. The learning facilitation in co-op occurs in two distinct environments, classroom-based instruction and experiential learning in authentic work settings. This presents special challenges for education quality.

Over the past two decades, quality management in HE has become increasingly important in the world [9]. A number of factors have promoted this development: government and industry have advocated the essence of a well-educated workforce for increasing productivity and for maintaining a competitive edge in the global economy. There are various approaches of quality management developed and used in industry. Total quality management (TQM) and ISO 9000 series [10][11] are briefly discussed below. TQM is defined as a management approach that aims to achieve and sustain long-term organizational success by encouraging employee feedback and participation, satisfying customer needs and expectation, respecting societal values and beliefs, and obeying statues and regulations. It is a comprehensive management approach which requires contribution from all participants in the organization to work towards long-term benefits for those involved as a whole. In the ISO 9000 context, the definition of quality refers to all those features of a product (or service) which satisfy the customer's requirements and comply with regulations applicable to the products or services. It is primarily concerned with continuous improvement by preventative action. This means that the organization must fulfill the customers' quality needs and regulatory requirements, while arming to enhance customer satisfaction, and to achieve continual improvement in pursuit of those objectives.

It is important to understand the special differences of education and industry when selecting quality management processes. One of the difficulties is to identify stakeholders and goals in co-op. The principal goal of any co-op programs is to facilitate student learning, to help him to transfer theory to practice, to develop generic skills and improve graduate employability. Students are in the center of co-op. A HEI is not a factory of producing students as products. In fact, students are co-producers, consumers as well as products. In order to success to manufactures products, students have to be active in the two different and interweaved processes of learning and teaching. Teaching is more similar to management rather than observing detailed activities. Learning, on the other hand, is similar to research and development instead of a set of processes. Besides, the different quality management principles and processes must be coordinated in on educating process.

\section{A Framework of Quality Management}

Currently, we are implementing co-op programs in our college, which integrate work-integrated learning (WIL) to different academic degrees. Students are the center of the programs. They are both consumers and co-producers. Teaching methods are also needed geared to the purpose. Various practice-oriented teaching and learning methods are investigated and put into use.

Special attentions are paid on the quality of educating activities occurred on the sites of industrial partners and the joints of the classroom instruction and WIL. A unified framework of quality management which integrates the quality measures from both the sides of the university and the partners is established, in order guarantee the successful completion of the co-op programs.

The framework comprises three quality components in the educating process (see Fig. 1): quality assurance, quality control and quality improvement. Quality assurance covers all education activities from the program conception, goal and quality standard, cooperative curricula design, 
teaching implementation, teaching and training services, and student graduation and employment. Quality control concerns the process that the all teaching and learning activities are monitored to ensure that all quality needs are being met and problems are solved on the spots. Data of performance are collected for the program analysis and improvement. Quality improvement consists of self- assessment, external evaluation and mutual evaluation of all the education efforts to check whether the program quality policy is implemented and the quality standards are met. It includes data analysis, status judgment, goals checking and improvement recommendation, etc.

\begin{tabular}{|c|c|c|c|c|c|}
\hline & Alignment (P) & Implementation (D) & \multicolumn{3}{|c|}{ Check and Action } \\
\hline Unversity & $\begin{array}{l}\text { University mission and goals } \\
\text { Co op programs objectives and goals } \\
\text { Criteria of partner selection } \\
\text { Quality policy } \\
\text { Evaluation methods and process } \\
\text { Sampling quality policy }\end{array}$ & $\begin{array}{l}\text { Co op programs development } \\
\text { Quality management regulations } \\
\text { Quality inspection } \\
\text { Change management } \\
\text { Resources support }\end{array}$ & \multirow{3}{*}{ 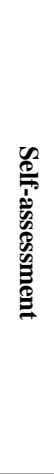 } & \multirow{3}{*}{ 范 } & \multirow{3}{*}{ 晜 } \\
\hline $\begin{array}{l}\text { College and } \\
\text { Department }\end{array}$ & $\begin{array}{l}\text { Partner selection and management } \\
\text { Work placement selection } \\
\text { Curriculum development } \\
\text { Quality standards } \\
\text { Educator training }\end{array}$ & \multirow{2}{*}{$\begin{array}{l}\text { Course selection and design } \\
\text { Instruction on campus } \\
\text { Work-integrated learning } \\
\text { Management teaching documents } \\
\text { Change control } \\
\text { Teaching activities monitor } \\
\text { Sampling quality supervision } \\
\text { Data collection } \\
\text { Status report }\end{array}$} & & & \\
\hline \multirow[t]{2}{*}{$\begin{array}{c}\text { Industrial } \\
\text { Partners }\end{array}$} & $\begin{array}{l}\text { Coordination of teaching and working } \\
\text { Placement preparing }\end{array}$ & & & & \\
\hline & Quality Assurance & Quality Control & \multicolumn{3}{|c|}{$\begin{array}{c}\text { Quality } \\
\text { Improvement }\end{array}$} \\
\hline
\end{tabular}

Fig.1. Overall structure of the quality management framework for cooperative education

Main activities of the quality components are performed at two levels. At the top managerial level, the board of the cooperative programs joined by university and partners takes charge of the strategies including the mission, long-time vision, quality regulation and policies. At the executive level, the college is responsible for designing discipline program and curricula, and quality management involved in teaching activities of both sides on the campus and in work settings. Relationship management of various partners also belongs to the work at executive level.

Companies will participate in the co-op programs when they ensure that the goals of the co-op are aligned with theirs. The placement is ready for WIP when the work of training engineers for education, preparing infrastructures, collecting domain experience and working cases has been finished. Due to limited space, other activities in quality management are not described in details.

The educating activities are distributed in the whole process and dynamically incorporated in Deming's PDCA (Plan-Do-Check-Check) cycle [12].

Planning (Strategic Alignment) includes definition of the quality policy, setting up long term goals and objectives, promoting cooperation with industry and community. The need of industries and students are analyzed, from the rate of employment and graduation, graduate incomings, employee and students. This stage may determine state and industry standards requirements and how they will be assessed. Educators develops curriculum to assure a clear continuity of instruction throughout the student's education. They develop individual goals to improve the instruction. By integrating the recommendations for improvement, co-op programs and curricula are revised.

Do (Implementation) is the next step when specific education activities are carried out to achieve the planned goals and objectives through teaching/learning, internal quality systems with external practices, etc. Developing ownership and personal motivation among educators and students are important preconditions to achieve coherence between their goals, objectives and implementation. Within set parameters, teachers vary the delivery of instruction based on each student's learning rates and styles and varying teaching methods. Special quality management measures focusing on WIL are developed and applied. During the program running, process monitor and quality control measures contains supervision, staff training on the job or off duty. Data collection methods include sampling, student interview, survey, status report, and semester summary.

Check (Evaluation and Assessment) consists of data collection and results evaluation. Formal and informal assessments take place continually, from review of teacher's instruction manual, 
assessments of progress reports in the mid-semester, to annual standardized tests. Throughout the school year, if assessments show students are not learning as expected, mid-course corrections are made such as re-instruction, changing teaching methods and more direct teacher mentoring.

Action (Improvement) of improvements are undertaken, since quality management is a continuous and systematic process, it must undergo constant review combining self-assessment with external evaluation, processing feed-back and organizing procedures of changes. When goals are met, the curriculum design and teaching methods are considered standardized. Teachers share best practices in formal and informal settings. Results from this cycle become input for the beginning phase of the next PDCA cycle.

\section{Conclusions and Future Work}

The paper proposes a framework of quality management for higher co-op programs containing WIL as an essential composition. It integrates quality assurance, quality control and quality improvement in one system. The activities are distributed in the whole framework and organized in the PDCA cycle, embodying the principles of general quality management principles such as TQM and continuous improvement efforts. In the future, concrete components of the framework, sub-process such as program goals setting up, industrial partner selection, and formal teaching process monitor, and quality regulations have to be developed and documented in details. Besides, the framework will be put into practice in different programs and validated according to the set goals such as the satisfaction of student and employers.

\section{References}

[1] M. Brookes, N. Becket. Quality management in higher education: A review of international issues and practice. International Journal of Quality Standards, 2007, 1(1): 85-121.

[2] R.K. Coll, K.E. Zegwaard (Eds.). International handbook for cooperative and work- integrated education: International perspectives of theory, research and practice. Lowell, MA: Work Association for Cooperative Education, 2011.

[3] L. Yu. Research on the "cooperative education" model cultivating in higher vocational education. International Journal of Education and Management Engineering, 2012, No.1:35-41.

[4] J.P. Jallade. International approaches to education: a review of some major cooperative programmes. European journal of education, March 2011, 46(1) pp. 7-24.

[5] E. S. Sovilla, J. W. Varty. Cooperative and work-integrated education in the US, past and present: Some lessons learnt. In [2] pp. 3-15.

[6] A. Göhringer. University of Cooperative Education: the Dual System of Higher Education in Germany. Asia-Pacific Journal of Cooperative Education, 2002, 3(2):53-58.

[7] J.K. Huggins. Engaging Computer Science Students through Cooperative Education. ACM SIGCSE Bulletin, December 2009, 41(4):90-94.

[8] S. Dressler, A. E. Keeling. Benefits of cooperative and work-integrated education for students. In [2] pp. 261-275.

[9] G. D. Doherty. On quality in education. Quality Assurance in Education, 2008, No.16: 255-265.

[10] D. Hoyle. ISO 9000 Quality Systems Handbook (5th ed.), Elsevier Ltd., 2006.

[11] R. A. Cardoso. Implementing Quality Management Systems in Higher Education Institutions. Journal of Total Quality Management, 2010, No.5:13-17.

[12] W. E. Deming. Out of the Crisis. Cambridge, MA: MIT Center for Advanced Engineering Study, 1982. 